\title{
Performing the Egyptian revolution: Origins of collective restraint action in the Midan
}

Keywords: collective restraint; contentious performance; regime-society relations; Midan; Egypt

\section{Adham Saouli}

'By the mere fact that he forms part of an organised crowd', argued Gustave Le Bon (1896/1946, 32), the pioneer of crowd psychology, 'a man descends several rungs in the ladder of civilization. Isolated, he may be a cultivated individual; in a crowd, he is a barbarian...a creature acting by instinct. He possesses the spontaneity, the violence, the ferocity...to be induced to commit acts contrary to his most obvious interests and his bestknown habits.'

In his struggle to secure an honourable exit from power in the course of the Egyptian revolution in 2011, the deposed president, Housni Mubarak, would have wished Le Bon to be right. He may have hoped that the demonstrators of Midan al-Tahrir (Liberation Square; henceforth Midan) in central Cairo to be ferocious and instinctive in expressing their political, sectarian, and social beliefs. He may have wished to see Islamist banners, the Christian Copts being attacked, the army violently confronted, or the flags of Iran or the US waved. But the demonstrators hand in mind a different performance for the floundering president and the public. They exercised what I call in this study a politically conscious, yet temporary, collective restraint action. Beyond the violent clashes in the first four days of the revolution (25-28 January), in the Midan demonstration (29 January-11 February)_the revolutionaries aimed to deflate the regime's strategy and narrative-political tricks of survival which Mubarak nurtured in his 30-year rule, which many Egyptians have learned to decipher-by accentuating and overtly dramatizing the 'peaceful', 'civil', 'nationalist' and 'domestic' nature of the revolt. The politically heterogeneous crowd managed to inhibit many of its divisions and to act collectively, promising the public of an alternative society. A society, as the demonstrators envisioned, where political and religious tolerance will be high, where security will be maintained, where sexual harassment will be diminished, and where the streets will be clean. The performance succeeded, managing to persuade the Egyptian and international publics to back its desire for Mubarak to step down ${ }^{1}$. 
Why did the demonstrators repress their political and religious beliefs? Why did they refrain from using violence? Why did they feel obliged to persuade the public of their acts? Why did they accentuate certain slogans and inhibit others? Studies on various forms of socio-political protest have examined the origins, behaviour, rationality, and variations of social movements, revolutions, demonstrations, street marches, and riots ${ }^{2}$, but in this literature the element of collective restraint has not been given sufficient attention. ${ }^{3}$ Other studies show how leaders like Egypt's Nasser (Khashan, 1995), Congo's Lumumba (Klein and Licata, 2003), and Ukraine's Yuschenko (Beissinger, 2011), or organisations like Hizbullah (Saouli, 2011) are conscious of the socio-political structures they operate in and instrumentally adopt or desist from using certain discourses and actions, yet these studies have not theorised unorganised collective restraint action or examined it empirically.

In this paper I aim to fill this gap by examining the socio-political origins of collective restraint action in the Midan. I ask how and under what conditions do politically heterogeneous groups exercise collective restraint? I build on different approaches in sociology, particularly the social movements literature and social psychology. This, however, is a work of political science; I treat the Midan demonstration as a critical event in regimesociety relations, and a continuation and development of existing 'repertoires of contention' (Tilly, 2006, p. 35). Building on the work of Norbert Elias (1939/1990), I argue that Mubarak's regime, which garnered a monopoly over coercive power and the national narrative - representing itself as the guardian of unity, stability, and sovereignty-formed an external constraint for political change in Egypt. This external constraint generated into internal collective restraint in the Midan. The collective restraint, I show, was motivated by an attempt to discredit Mubarak's strategy and rhetoric. Whilst this collective behaviour appeared as 'spontaneous', I argue that this spontaneity originates from a collective consciousness of: (a) regime strategy and narrative; (b) dominant socio-political values; and (c) existing repertoires of contention. This form of collective restraint action, I find, was temporary. When Mubarak stepped down, the compulsion for collective restraint subsided.

I present this argument in three sections. Firstly, I conceptualise the Midan demonstration as a 'contentious performance' (Tilly, 2008), and then define collective restraint action as one variant of contentious performances. Secondly, I demarcate the main factors that shape and contribute to collective restraint action in regime-society struggles. Thirdly, I present an empirical analysis of the Midan demonstration, examining how and why the demonstrators exercised collective restraint. The empirical section is based on first-hand accounts and semi-structured interviews I carried out in Cairo in 2012. ${ }^{4}$ 


\section{Contentious performances and collective restraint}

The Midan demonstration, which lasted for 14 days (28 January to 11 February 2011), can be conceptualised as a 'contentious performance': 'occasions on which people break with daily routines to concert their energies in publicly visible demands, complaints, attacks, or expressions of support before returning to their private lives' (Tilly, 2006, p. 49). Collective claim-making demarcates an actor with an identity (say a political oppositional group), who carries specific claims against another (such as a government), and who demands recognition as a legitimate social actor (Tilly, 2008, p. 89). The Midan demonstration collectively identified itself as a revolutionary movement, representing a broad base of Egyptian social segments (workers, writers, students, religious men, soldiers etc.) that was united under a clear, but politically disruptive, program: Al-shaab urid iskat al nizam! (the people want the fall of the regime!).

In making collective claims, however, peaceful activists, revolutionaries or armed insurgencies have in mind a third party: a public. The presence of a public - as a latent political force-forms a structural constraint that shapes actors' discourse and action in contentious politics. Since the public can be mobilised in support or in defiance of a claim, and since this can be decisive for political battles, contentious politics is also about performance. A performance 'involves representation in a dramatic form, as movements engage emotions inside and outside their bounds attempting to communicate their message. Such performance is always public, as it requires an audience which is addressed and must be moved' (Eyerman, 2006, p.193). To mobilise the public, a claim-maker will invest in speeches and symbols aiming to 'frame' an event in ways that resonate with its own political objectives and public values. Framing 'provides the sorts of shared meanings necessary to facilitate social mobilization' (Schewdler, 2006, p. 162). These frames must culturally resonate with a society's social expectations and values (Williams, 2004, 105). During the Egyptian revolution, the regime, in a typical tactic to de-legitimise the opposition, framed the demonstration as 'foreign funded and orchestrated', which will bring 'chaos' to Egypt. On the other hand, the demonstrators had to convince the public that their movement was 'peaceful' and 'nationalistic'. As Alexander (2011, x) observes, the Egyptian revolution relied on its 'cultural power': 'its ability to project powerful symbols and real-time performance, plotcompelling protagonists and despicable antagonists; to stimulate and circulate powerful 
emotions; to organize exemplary solidarity; to create suspense; and finally to minister ignominious defeat to dark and polluted adversaries...'

I intentionally define the Midan crowd here as a performance to distinguish it from a protest. As I will illustrate below, the first four days (25-28 January 2011) of the revolution consisted of a protest: a popular reaction expressing frustration at the Mubarak regime. The remaining fourteen days, however, revealed the emergence of a political actor represented in the Midan that is responsive to regime behaviour and to public apprehensions. This response involved collective restraint: a contentious performance in where a crowd controls and regulates its behaviour by suppressing certain political emotions, slogans and actions. This may include inhibiting in-group divisions and representing a united front, curbing the use of violence, and ostensibly conforming to social values and expectations. A collective restraint action is always embedded in, and is conscious of, a socio-political context. It is motivated by specific political aims, and is in pursuit of wider social acceptance and legitimacy.

Collective restraint is essentially about social representation. Although the Midan demonstrators had a common Egyptian identity, they were politically and religiously heterogeneous. What emerged in the Midan is a representational sense of shared identity: this 'identity is shared in the sense that a set of people define themselves in terms of the same category membership. This engenders a cognitive shift whereby crowd members adopt a common perspective on which to base thought and judgment' (Reicher, 2011, p. 438, italics original), and we should add: action. This representational identity relates to-and is shaped by - the social context and not the actual identity of a crowd. As Alexander observes, the meaning contending actors seek to demonstrate for others "may or may not be one to which they themselves subjectively adhere; it the meaning that they, as social actors, consciously or unconsciously, wish to have others believe'(2006, p. 32).

However, why do individuals and crowds choose to represent themselves? How do they become conscious of what to restrain or expose? The collective restraint action in the Midan was, largely, unorganised, but what are the origins of this ostensibly 'spontaneous' collective action?

\section{Theorising collective restraint action in regime-society struggles}

For Norbert Elias, socio-political interdependencies constrain social action, obliging individuals and groups to exercise self-restraint as they seek to achieve their goals. In his monumental study on The Civilizing Process (first published in German in 1939 and later 
translated into English in 1978), Elias explored the social conditions that generate restraint. He examined the changing culture relating to manners in European history (and the booklets that educated readers of when, where, and how to burp, spit, or blow one's nose in the presence of others) attributing this to macro civilising processes. For Elias the knot that ties these processes is state formation: namely the monopolisation of the use of violence, which pacified large territories, facilitating trade, the growth of cities, the division of labour, monetisation, and, crucially for war-making, the monopolisation of taxation, which in turn reinforced the monopolisation of coercion (Ibid., pp.185-344).

This social integration tied more individuals and groups in a social web, making them interdependent (Ibid., p. 367). The actions and attitudes of an individual, his or her opportunities for success or failure, began to be shaped and determined by knowledge of, and conformity with, the social standards imposed by that interdependence. For Elias, and this is central to the study of collective restraint, what happens in the civilising processes is that the external social constraints that individuals confront as a result of their interdependence begin to shift and transform into internal self-restraints (Ibid., p. 109):

The social standard to which the individual was first made to conform from outside by external restraint is finally reproduced more or less smoothly within him or her, through self-restraint which operates to a certain degree even against his or her conscious wishes.

Social interdependence cultivates the self-restraint skills of foresight and rationalisation. With foresight and rationalisation social actors repress their immediate shortterm social needs in anticipation of long-term success, as Elias observes: 'Each man, as it were, confronts himself. He "conceals his passions", "disavows his heart", "acts against his feelings". The pleasure or inclination of the moment is restrained in anticipation of the disagreeable consequences of its indulgence' (Ibid., pp. 398-9). Becoming conscious of the consequences of one's acts on his or her social success and survival rationalises human conduct. Thus, for Elias:

Continuous reflection, foresight, and calculation, self-control, precise and articulate regulation of one's own affects, knowledge of the whole terrain, human and non-human, in which one acts, become more and more indispensible preconditions of social success. (Ibid., 398)

The centralisation of the use of violence in a delimited territory, for example, acts as an external social constraint, making 'the use of violence more or less calculable, and forces unarmed people in the pacified social spaces to restrain their own violence through foresight and reflection' (Ibid., 373). 
Elias, to be sure, examined long processes of European social development, but his central thesis on how human interdependence establishes compulsive and impersonal external constraints, which remould social behaviour into self-restraints, and his notion of the 'knowledge of the whole terrain' are very useful in examining collective restraint in regimesociety relations. To account for collective restraint action in regime-society relations, however, I suggest three interrelated factors: (1) regime strategy and narrative; (2) sociopolitical values; and (3) repertoires of contention (Tilly 2007). These factors, which vary across cases, form external social constraints, which set the parameters for collective political action by rival groups.

Regime strategy and narrative: Unlike most European states, which took centuries to crystallise, late state-builders of the $20^{\text {th }}$ century, including the Middle East, installed political regimes that were vulnerable to reconstruction. ${ }^{5}$ Many authoritarian regimes sprang up as a reaction to colonialism in different parts of the developing world in the 1950s and 1960s aiming to achieve national independence and socio-economic reforms. When these regimes captured state institutions (such as the police, security, army, government), they attempted to centralise and consolidate their power through the monopolisation of the means of violence, ideology, and, to varying degrees, economic resources (Saouli, 2012, pp. 8-27, 49-61).

In their survival strategies, regimes centralise the tools and use of violence; they repress, or when possible incorporate, their rivals who attempt to threaten their power; they economically reward or punish friends or rivals, respectively; they divide the opposition; they establish bogus political opposition parties and hold fraudulent elections (Chehabi and Linz, 1998). Crucially, regimes also produce a political narrative that is drawn from existing sociopolitical values (see figure below). This is not an objective history of a country; rather, as Walton argues, narratives are constructed 'for the aims of present action'...Narratives make claims for the virtues of their individual and institutional authors, often as a counterpoint to rival claimants' (quoted in Tilly, 2005, 211). In monopolising the national narrative, in representing themselves as the sole guardians of national sovereignty and unity-defining who is the 'loyal' citizen or the 'traitor' - regimes establish frameworks of public discourse, ingraining what Wedeen calls 'the rhetorical context' $(1998,507)$.

Regimes, thus, become the locus of a social web that ties people together; they form an external constraint that delimits political action. The quest for socio-political success and survival invites individual and collective restraint. In Syria, for example, the Baathist regime had 'disciplinary effects' on many Syrians who, whilst not necessarily believing in Hafez 
Assad's cult, had to 'act as if they do' (Wedeen, 1998, 505, italics original). As one Syrian observed, 'People don't post the signs because they love him, but because the system is selfenforcing and people are accustomed to it. People have internalized the control' (quoted in Wedeen, 1998, pp. 506-7, 512; emphasis added). In representing itself as the beacon of Arab nationalism and resistance to Israel and as a guardian of unified Syria, the regime 'inhibited collective action and opposition' (Ismail, 2011, pp.541, 540).

Two points are in order. First, regime strength varies across cases. The higher the regime dominance over different social spheres, the more collective restraint rival groups will exercise, and vice-versa. Second, when socialising into authoritarian regimes, individuals and groups become conscious of regime strategy and narrative. This consciousness is crucial for collective restraint when opportunities for mobilisation against a regime arise.

Socio-political values: a second factor that shapes collective restraint action is the dominant values a society holds, or what Williams calls a 'cultural environment': 'the socially and culturally available array of symbols and meaning from which movements can draw'(2004, 96, emphasis original). These originate from a country's cultural and religious make-up, and are shaped by its political development (Saouli, 2012, 15-28). In contentious performances, actors must appear to conform to and represent these standards._The cultural environment, accordingly, shapes how actors frame situation. Of these standards is the "national interest" or "national unity", which political actors must appear to promote. In divided societies such as Lebanon, Syria, or Ukraine, 'national consensus', dictated by the need to incorporate all communal groups in government, is a norm to be respected. In postcolonial states, the norm of 'national independence' is a sacred value that leaders have to represent.

But these norms and values become 'open for rival interpretations and potential transcendence in meaning' (Williams, 2004, 104). When an opposition rebels against a regime, it is partly challenging the regime's monopoly over the representation of certain socio-political values. For example, in 1997 Jordanian activists protested against an Israeli trade fair held in Amman. In an attempt to 'deflate government's ability to react with repression' and to prevent the regime from instrumentalising identity divides, the demonstrators performed a pro-nationalist identity, which 'imagined a common Jordanian identity, one that crosses religious, ethnic, class, and regional divides' (Schwedler, 2005, p. 170-2). Similarly, in Ukraine's Orange Revolution, Yushchenko was conscious to frame the campaign 'in civic rather than ethnic nationalism' to unite the heterogeneous crowd (Beissinger, 2011, p. 35). As such, some movements 'choose - and some are forced - to use 
cultural expressions that originate with their rivals in order to achieve a place in public life' (Williams, 2004, 103). In the initial months of the Syrian uprising (March-October 2011), demonstrators represented themselves as the 'Syrian people', chanting "Not Sunni and not Alawi, we want freedom"' (Ismail, 2011, p. 543). Such a performance aimed to neutralise regime claims on the "dangers of sectarianism" and to break its monopoly over the representation of national values; it also appealed to the reluctant segments of the Syrian public - especially its minority groups who feared that they could be targeted should Asad's predominantly Alawite regime collapse.

Repertoires of contention form the third factor that compels collective restraint. As Tilly explains, the 'theatrical metaphor calls attention to the clustered, learned, yet improvisational character of people's interaction as they make and receive each other's claims' (2006, p. 35). Repertoires draw attention to both actors' knowledge of previous struggles (say with an authoritarian regime) and their ability to improve on existing tools of political protest; they inform movements of which strategies-violent or peaceful - and frames to restrain or pursue. For example, the socialisation of Islamic movements such as Hizbullah, the Muslim Brothers, or Turkey's AKP, in secular or multi-sectarian regimes, have restrained their political strategies and discourse making them more conducive to sociopolitical expectations and constraints (Saouli, 2011; Naguib, 2009; Mecham, 2004).

The organisers of the Midan demonstration, as I will elaborate, were informed by previous struggles with the Mubarak regime, insisting for example that the demonstration should be peaceful. But the unexpected influx of huge numbers of people required an improvisation of existing repertoires to cope with the challenges and opportunities of the moment: this is where organisation meets spontaneity. 


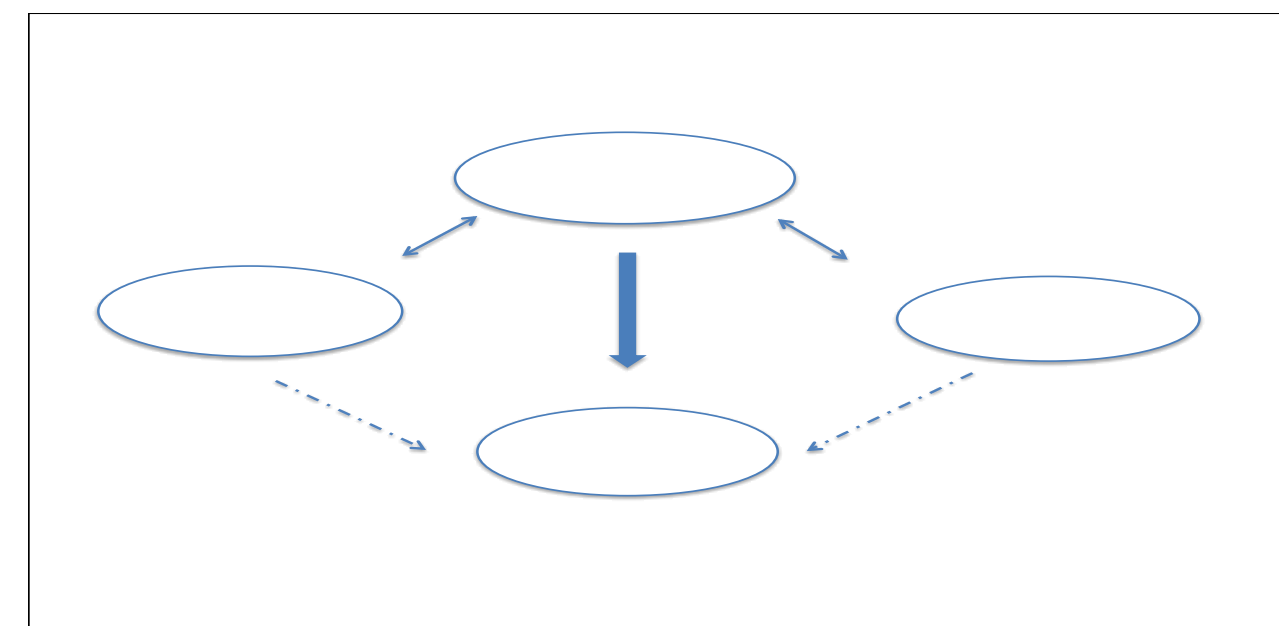

Figure 1. Socio-political origins of Collective Restraint Action (CRA) in the Midan

$\Longrightarrow$ Regime strategy and narrative as a determining factor of CRA

Socio-political values and repertoires of contention as contributing factors of CRA

Building on this framework, I will first provide a background to the Midan demonstration and then will examine how and why the Midan demonstrators exercised collective restraint. I argue that knowledge of regime strategy and narratives, of Egyptian socio-political values, and experience from previous struggles with the regime, have all motivated the exercise of temporary collective restraint, which was necessary to win over the Egyptian public and to defeat Mubarak's narrative. As Figure 1 illustrates, the Mubarak regime formed the external constraint that determined the collective restraint behaviour of the Midan demonstrators; political values and repertoires of contention, on the other hand, acted as contributing factors to this collective action.

\section{From Protest to Performance: The road to Midan}

The protest that erupted on 25 January 2011 was a continuation of contentious regime-society struggles, which started in 2000. In his first decade as president (1981-90), Mubarak consolidated his power by repressing a militant Islamic movement, a police mutiny, and by limiting the opportunities for the rise of any challengers (especially from the army) to his power. Through his regime's control over the public media, security agencies, and the parliament, Mubarak managed to maintain a stable rule through out the 1990s. The first signs of political dissent appeared in the early 2000s and were subsumed under protests in support of the Palestinian Intifada in 2000 and in opposition to the US-led invasion of Iraq in 2003. 
Gradually various political factions (Nasserites, Islamists, Socialists) began to express opposition to Mubarak's rule. In 2004, before a scheduled referendum to mark his fifth sixyear term, political and civil society groups, such as the prominent Kefaya! (Enough!) Movement, held public protests and called for democratic reforms, including a rejection of another term for Mubarak or succession to his son, Gamal (Clarke, 2011). In 2006 industrial workers in the private and public sectors held around 222 forms of protests (El-Mahdi, 2009, p. 100). On April 6, 2008 textile workers in the industrial cities of Mahalla and Kafr al-Dawar in the Nile Delta mobilised for a strike in their workplace. In solidarity, several associational groups and Facebook activists called for a national strike, demanding a minimum wage and an end to corruption and police brutality. The security forces repressed the protests, but the event gave birth to the April 6 Youth Movement, which would be a main mobiliser for January 2011 protests (Carr, 2012; El-Ghosaby 2012).

By Jaunuary 2011, however, four events heightened national frustration with the regime. First, the Israel war on Gaza of 2008/9 revealed the regime's incapacity to shape events in their neighbouring strip (many Egyptians believed the war decision was made in Cairo). Second, the rigging of the 2010 legislative elections, giving 97 percent of the vote to the NDP, showed the regime's intention to repress the opposition and to facilitate Gamal's succession. Third, in June 2010 security officers brutally beat to death a bloger, Khaled Said, in Alexandria. The incident exposed police brutality, reminding the public of the daily humiliation the force inflicted on many Egyptians. In response, activists established a Facebook page entitled 'We are all Khaled Said', which became a mobilising tool against the regime (Maghdi, 2011, pp. 39-42). Finally, the attack on the Al-Qiddisin Church in Alexandria on 1 January 2011, which led to the death of 21 people, revealed the security's incapacity to protect Egyptian Copts; many suspected that the regime had 'orchestrated' the attack to deepen sectarian fissures and to deflect attention from the Tunisian revolution (alMahmadi, 2012, p. 8). In December 2010, the 'We are all Khaled Said' Facebook page mobilised for a day of protest, intended on the National Police Day, 25 January 2011, calling for an end to police brutality and the resignation of the interior minister (Magdi 2011, pp. 5051). The fall of Tunisia's Bin Ali on January 14, which generated a 'melange of joy, shock and hope' in Egypt (Al-Sheikh, 2011, p. 24), however, led several political youth groups to meet and organise for what now came to be called a 'Day of Rage' on 25 January (Badawi, 2011, pp.64-66).

It is common to think of the Egyptian revolution as the '18-day peaceful revolt in the Midan'. This is not accurate. The first four days of the revolution (25 to 28 January) involved 
violent confrontations between the security forces and the revolutionaries, who burned tens of police stations and the Cairo headquarters of the NDP and tried to control the interior ministry. The street battles led to the death of hundreds and injury of thousands of citizens and police officers (Saad, 2012, p. 22; El-Ghobashy, pp. 22, 38; Badawi, 2011, pp. 78-79). The remaining fourteen days (28 January to February 11), however, revealed the emergence of a restrained collective actor centred in the Midan

Initially the police succeeded in preventing the revolutionaries from controlling the Midan; but when the police withdrew from the streets on January 28, the regime's coercive capacity began to falter, reflecting a shift in the power balance from the regime to society (ElGhabashy, 2012). As a consequence, or by regime design, police withdrawal freed thousands of prisoners, causing widespread looting. But the withdrawal facilitated the takeover of the Midan by the revolutionaries. The army's intervention on January 28 , however, imposed a constraint on further popular protest. Its intention not (and, possibly, inability) to repress the revolutionaries led the protest to transform into a political performance centred in the Midan. Typical of revolutionary situations, two blocs of contenders with different social representations confronted one another (Tilly, 2006, p. 159; Alexander, 2011, 14).

\section{Performing Collective Restraint in the Midan}

Egyptian activists observed a 'spontaneous [collective] consciousness' in the Midan. The protestors 'responded to police repression and bullets with flowers and peaceful slogans' (Hussein, 2011, p. 112; Maghdi, 2011, p. 53). Social psychologist El-Mahdi observed a 'great civilised revolution' (2011, p. 321).

The crowd in this revolution refutes Gustav Le Bon's, and other scholars', assumptions; for the crowd was prudent and rational: it did not exercise violence or destruction and, whilst more than 10 millions protested in Cairo and the provinces for many days, the movement remained peaceful and exercised self-restraint despite the regime's provocations...

These observations do not account for the violence that preceded Midan demonstrations (or the violence that took place in cities outside Cairo) and do not explain why the demonstrators spontaneously exercised collective restraint. To understand collective restraint, we need to demarcate an emerging structure of three interdependent actors: the Midan demonstrators, the regime, and the public. The demonstrators faced two external constraints that can specifically explain their temporary collective restraint. First was the regime, which by 28 January was weakened by police withdrawal and the ostensibly neutral stand of the military but which still possessed some leverage through the control of public 
media and Mubarak's remaining symbolic power. Second, was the Egyptian public (which the revolutionaries jokingly called 'hizb al-kanaba' (the couch party)) whose support was crucial for the success of the revolution or the survival of Mubarak. The Midan performance, with its symbols, action, and collective restraint, can be understood as a response to these two constraints.

\section{Silmiya!}

No slogan appealed to the Egyptian and international publics like 'Silmiya' (Peaceful!). Activists have cried Silmiya! before and during the Egyptian revolution whenever police forces or the army confronted them. During the demonstration many banners read: 'Peaceful demonstration, no destruction' (Al-Jamal, 2011, p. 50). In a collective attempt to avoid any clashes with the army, but also to draw it closer to the revolutionaries, the demonstrators shouted: 'The people and the army are one' (The Republic of Tahrir). But this slogan and the concomitant restraint of violence have deeper socio-political origins. The army in Egypt was not only seen as the 'guardian of the nation', but was also perceived as an 'extraordinary institution that is above accountability' (Darwich, 2013). In his final (10 February) appeal to the Egyptians, Mubarak invoked this social perception when he recollected his war achievements: 'I was young as Egypt's youth today, when I learned the Egyptian military honour, allegiance and sacrifice for my country...I lived the days of the (Suez) crossing, victory and liberation' (BBC, 2011). As a response, the demonstrators had to conform to public perceptions by accentuating that they and the army 'are one', and that their opposition to Mubarak is not a rebellion against the military.

Origin of this response and the emphasis on Silimiya! is also found in the sociopolitical value that dictates a need to preserve "public order and stability". The Mubarak regime through its media and official discourse portrayed the idea of political activism, including peaceful protest and demonstration, as 'a recipe for instability in Egypt' (Hussein, 2012). In the public's mind, political change or reform was indelibly linked with political chaos. Such a belief was not unfounded. During the 1980s and 1990s the regime fought a war with militant Islamic groups that targeted regime officials and tourists (Naguib, 2009, pp. 111-2). The ability of the regime to survive these attacks, however, led it to extend its violent repression to the opposition; thus during the Mubarak reign 'Egyptians lived in a state of fear, which kept them away from politics' (El-Mahdi, 2011, pp. 296-7).

The barrier of fear from the authorities, however, began to 'gradually erode' when activists of Kefaya! and the April 6 Movement staged numerous peaceful demonstrations in the 
years preceding the revolution (El-Mahdi, 2011, p. 297). These also contributed to changing the public's perception of political activism. The Midan demonstration was a continuation of these repertoires of contention. As journalist and Midan demonstrator Tabie recounts, the emphasis on the peacefulness of the demonstration was to show the broader society that "we are not violent or aiming to cause chaos as the regime is narrating' (Personal interview, 2012). During the revolution, the regime capitalised on the street-fighting and looting of the first four days to instil public fear: in some cases warning of homes being attacked and women being raped (El-Mohamady, 2012, p. 30; El-Baltagy in 'Silmiya'). But crucially, the regime wanted to represent itself as the indispensable custodian of security and stability. In his first address (01 February) to the Egyptian people, Mubarak argued that, 'The events of the last few days require us all as a people and as a leadership to choose between chaos and stability' (Reuters, 2011). Many political activists, however, understood this tactic: a choice the regime imposed on the public, which, in a nutshell, they deciphered as 'Me [Mubarak] or chaos' (El-Mahdi, 2011, pp. 304-5; el-Mohamady, 2012, p. 30) ${ }^{6}$.

The Midan demonstrators wanted to deconstruct regime tactics and narratives. Activists recall how they curbed any attempt to cause trouble within the Midan. In one incident, some demonstrators tried to break into shops around the Midan; however, others stopped them and emphasised the need to 'protect the public's properties' (Nasser qutoted in Saad, 2011, pp. 834). In another, a regime supporter tried to convince the activists to break the demonstration, as in his speech Mubarak promised to leave power in 6 months, but when one demonstrator wanted to beat up the 'regime agent' other activists directly stepped in to restrain him. For Tabie "we wanted to show that we believe in dialogue not violence; this was not an Iranian revolution!' (Personal interview, 2012). More importantly, however, demonstrators wanted to keep the Midan safe from regime infiltration. Accordingly, security checkpoints were established at the main entrances of the Midan ('Silmiya'). The checkpoints became increasingly important after the 'Camel incident' on 02 February 2011 in which regime supporters tried brutally to invade the Midan with camels in a regime-inspired and desperate attempt to end the demonstration. The attempt was aborted. ${ }^{7}$

It was also important to reassure the broader public of the peacefulness of the movement by presenting a counter-representations against regime propaganda. The message was transmitted by a 'newspaper' published in the Midan, social communication networks, satellite televisions (especially anti-Mubarak Aljazeera) and by direct telephone calls to families and friends (El-Mahamady, 2012, p. 30; Personal interviews, 2012). As one activist 
recalls, the aim was to 'correct [the regime's] narratives, and refute [its] lies' (Mohammad quoted in Saad, 2011, p.53).

\section{Eid Wahda!}

It is not uncommon for organised political forces to strategically and temporarily unite to defeat a common rival. However, it is notable how ideological and religious divisions 'evaporated' in the unorganised crowd of the Midan: 'you can see the Muslim beside the Christian, the Liberal beside the Ikwani [Muslim Brother], the Leftist beside the Salafi' (elMahdy, 2011, p. 293; Saad 2012, 43). Activists argue that the goal of overthrowing Mubarak united the politically heterogeneous crowd. Before the revolution, regime change formed the 'least-common-denominator goal' of the Egyptian opposition (Clarke, 2011, p. 406). But the slogan 'Eid Wahda!' (We are all one!), which the demonstrators cried (The Midan Republic), is, like Silmiya!, not simply a 'spontaneous' reaction. Rather it was a collective conscious response by Midan demonstrators to appeal for public recognition and support. This response had origins in the socio-political value of 'national unity', which the Mubarak regime claimed to protect. The slogan and the representation of a united force was also an attempt to deflate the regime strategy that continuously aimed to capitalise on socio-political cleavages to maintain power. In this response, demonstrators restrained their ideological and religious associations and accentuated national unity.

At an ideological level, the demonstrators responded by emphasising that their movement is 'civil' (read secular), not Islamic. Like the fear of instability that the regime diffused in society, Mubarak accentuated the threat of Islamic rule should his regime fall: a fear which echoed the worries of many segments of Egyptian society, of Mubarak's regional (especially Arab Gulf) allies, and his Western supporters. His formula here, which the demonstrators tried to deconstruct, was: 'Me or the Islamists'. In the Midan, the Muslim Brothers (MB), which was the main organised opposition group, strategically subdued. As Mohammad Albeltagy, an MB member, notes: 'From the beginning we were careful not to be in the forefront of the protests' (Silmiya 2011; Personal interviews, 2012). Whilst this response by the organised MB was expected, non-organised Midan demonstrations were also conscious to maintain a 'civil' appearance to the demonstration. 'We concealed our ideological inclinations', Tabie recounts, 'the regime's propaganda always threatened the public of the rise of the Islamists; we wanted to show the opposite: this wasn't about the Islamists; this is about all Egyptians regardless of their religious or political ideology' (Personal interview, 2012). One banner read 'No Muslim Brothers, no partisanship; this is a people's revolution' (el-Jamal, 
2011, p. 16). When an 'apparently' organised group of MB women joined the demonstrations, Ahmad Abdel-Hamid, a Midan demonstrator with an Islamic leaning, asked them not to carry partisan slogans because the regime wants to 'frighten the public and international forces of the MB; it was necessary to keep all slogans hidden' (Personal interview, 2012).

The demonstrators represented themselves also as a collective political actor that transcends religious cleavages. This collective conscious attempt targeted the hesitant Christian segments of Egyptian society (the Coptic Church cautioned against participation in the demonstrations); but was also crucial to deconstruct Mubarak's narrative, which represented him as the 'bulwark' against religious divisions. Here, banners depicted the Christian cross and the Muslim crescent interlinked to one another, which in Egyptian memory is reminiscent of the national unity that manifested in the uprising against British colonialism in 1919-1922, and which has been reproduced in school curricula, art, and cinema.

The conjuring up of these national values preceded the Egyptian revolution, however. Previous 'cycles of contention' established 'space for overcoming ideological divisions' (ElMahdi, 2009, p. 96). The violent attacks against the church in Alexandria in 2011 led many to protest after Facebook activists called for a silent protest in 'black in commemoration against the victims of terrorism' and to 'emphasise the unity of Egyptians and their common destiny' (Magdi, 2011, p. 49; El-Mohamady, 2012, p. 9). In the Midan one demonstrator carried a banner accusing Mubarak of 'ingraining [Christian-Muslim] sedition' (Saad, 2012, p. 164). In another - now iconic representation of the demonstration - a group of Christian youth stood in a circle to protect their Muslim counterparts as they prayed. A Christian mass was held. Ihab el-Kharat, a member of the Egyptian Anglican church, recalls: 'I never believed that I could read from the Bible in the Midan in front of a million Muslim' (The Repblic of Tahrir 2011). This Midan performance stripped the regime of its alleged monopoly as the guardian of national unity.

Mubarak also employed his remaining symbolic power to drive a wedge between the movement and the public. In his final speech (10 February) he presented a dramatic narrative, which led many to leave the Midan: 'I never sought power or fake popularity. I trust that the overwhelming majority of the people know who Hosni Mubarak is. It pains me to see how some of my countrymen are treating me today' (BBC 2013). One retreating demonstrator recalls how 'Mubarak played the role really well' (Silmiya). But to maintain their unity, activists tried to 'thwart this psychological pressure' (El-Mahdy, 2011, pp. 312-3) and 'defused a message of fear' (Tabei, 2012; Seif, 2012). Through direct communications with family and 
friends, demonstrators threatened that if they were to vacate the square the regime will persecute and possibly kill them (The Republic of Tahrir, 2011; Personal interviews, 2012).

\section{Performing the Alternative Society}

The Midan demonstration was also a collective promise of what Williams $(2004,106)$ calls 'visions of the good society' . This society conformed to Egyptian socio-political values of "nationalism" and "national independence"; but it also envisioned an Egyptian society with a democratic system, clean streets, and an absence of sexual harassment. In short, 'The Republic of Tahrir' (2011; El-Mahdi, 2011, p. 291) was a collective 'utopian' vision of a world the revolutionaries wanted to make and represent (Shokr, 2012, p. 42). Nevertheless, performing this utopia and the curbing of socio-political affects that accompanied it constituted another attempt by the demonstrators to reframe regime propaganda and to gain public recognition.

Accusing the opposition of collaborating with external forces is a political rite that the Mubarak regime observed on a routine basis. Mubarak's final struggle with the revolutionaries was no exception. Public and pro-regime media accused the demonstrators of being part of an 'external conspiracy', of being paid 50 EUROS to camp in the Midan, and of enjoying free meals from KFC (El-Mohamady, 2012, p. 36). Through these accusations, Mubarak aimed to alienate the opposition from the public and to incite divisions within it. Whilst the regime's decadent strategy rejected improvisation (in some cases accusing the demonstrators of simultaneously collaborating with the US, Israel and Iran and Hizbullah!), the opposition has learned from previous struggles with the regime to debunk these allegations. In the Midan the message that the demonstrators wanted to transmit to the public was: we are Egyptians! And are worthy of your support! One demonstrator carried a banner saying 'KFC is closed, stupid!' Another exhibited Egyptian bread and vegetables with a banner reading 'This is the KFC!' (AlJamal, 2011, p. 44). The demonstrators performed nationalistic songs (especially of Sayed Darwich, Sheikh Imam, Hafiz) which, in addition to arousing the nationalist and revolutionary spirit (Saad, 2012, p. 71), attempted to accentuated the nationalist character of the demonstration. When TV presenter, Ahmed Allesily, invited the (pro-Mubarak) public television broadcasts to the Midan, many demonstrators protested and began to chant 'down with Mubarak'. But Allesily cautioned them that the public television would not air this; instead, he urged the demonstrators to 'chant nationalist songs for Egypt, so the people at home will understand that we are not traitors' (Silmiya! 2011).

The Midan offered a democratic vision for a country that lacked any substantive democratic experience. 'In the Midan you could present any view; you only needed to write 
your opinion on a placard and tour around with it in the Midan' (Saad, 2012, p. 44). Members of different ideological inclinations freely debated political issues, whilst the 'radio station' and the 'newspaper' that emerged in the Midan guaranteed a balanced representation of different political views. 'The spirit of the Midan transcended any sectarian, provincial, or even ideological inclinations' (Alam, 2011, p. 152). Indeed, in forming an alternative society, the Midan was also a safe haven for individuals threatened by regime thugs that terrorised the public in surrounding areas (Personal interviews, 2012). As El-Mahdi observes, in passing through the checkpoints into the Midan you realise that you have entered a 'different zone' (2011, p. 293). In the Midan 'everyone had a place':

Rebels young and old, professionals, factory workers, friends and families, performers, lovers, street vendors... a spirit of mutual aid prevailed. Canteens offered free food to anyone in need, make-shift clinics provided first aid to the wounded and volunteers...Evenings gave way to music and poetry. (Shokr, 2012, p. 42)

The Midan performance became, as Reicher observes of crowds, 'the imagined community made manifest' (2011, p.441, italics original). The performance of the utopian society, the curbing of political divisions, and the accentuation of a nationalist, democratic and tolerant demonstration aimed to reclaim the nation from Mubarak's domination. During the revolution, one activist uploaded a video on YouTube to show the 'truth about Tahrir', adding a plea:

I made this video to show the world that our historical revolution is a clean [,] civilized and modern revolution, not driven by any foreign hands or religious groups as shown in some unreliable media channels!!! Please share it with those who didn't go to Tahrir and [are] watching the revolution through Aljazeera!!!! (The Truth about Tahrir 2011)

The regime continued its struggle, however. In the course of the demonstration, in addition to portraying the activists as 'foreign agents', regime-dominated media accused them of polluting the square and of having sex in tents-accusations that attracted counter proregime demonstrations (El-Mohamady, 2012, p. 55). Partly to keep the square they inhabited clean, and partly to refute regime propaganda, activists collected trash and made it a point to keep the square (which before the revolution was a 'din of pollution and congestion' (Shokr, 201, p. 42)) tidy. On the other hand, although Egypt suffers from high levels of public sexual harassment against women, in the 14-day Midan demonstration, no incident of this sort was recorded (Personal interviews, 2012). The physical confinement of the crowd in the Midan and the threat this would cause for potential perpetrators may explain the restraint. But plausible also is that the collective restraint exercised in the Midan was driven by the need to preserve the unity of the crowd against regime verbal onslaughts, by providing a safe haven to 
attract public (especially women) support, and to represent moral values that Egyptians aspire to realise.

\section{Conclusion}

The Midan collective restrained performance deprived Mubarak of his symbolic power. On 11 February 2011 he stepped down. The external constraint that had ingrained a regime of socio-political restraints collapsed ${ }^{8}$. On that night, the first case of sexual harassment was recorded in the Midan ${ }^{9}$. The two years that have followed revealed a shift in power from regime to society. Attacks on policemen became a noticeable feature on Egyptian streets. Political divisions between the Islamists (who, after decades of restraint, became more vocal about their political and sectarian opinions) and the secular opposition (which fears the emergence of an authoritarian Islamic state) developed into bloody confrontations - signalling the existence of a deep-rooted civil conflict. Mistrust in the security forces gave rise to clandestine groups such as the 'Black Block', which espouses the use of violence when necessary to 'protect the goals of the revolution' against Islamist 'militias' (Matta, 2013). The flag of the 'Republic of Port Said' flew in the province in defiance of a government decision to curb the bloody protests that erupted against a court decision (Awad, 2013).

In this article I studied the Midan demonstration during the Egyptian revolution of 2011, by shedding theoretical and empirical light on the notion of collective restraint action. In examining the Midan collective action and the protests that preceded it, the paper corroborates existing literature that treats collective behaviour as 'socially meaningful' (Reicher, 2011). Collective restraint, I showed, is one example of such social deliberation. In examining collective action in regime-society struggles, however, I went further to locate the socio-political sources that motivate collective restraint. I showed that the ostensibly 'spontaneous' action in the Midan can be attributed to a collective consciousness of regime strategy and narrative, socio-political values, and repertoires of contention as external constraints that delimit political action and motivate restraint.

The paper finds that the Mubarak regime had a determining effect on the collective restraint action of the demonstrators; but the study also shows that this only became possible after the protest transformed into a contentious performance centred in the Midan. With Mubarak's fall, the locus of the system of external constraints which he had established, and which had structured the behaviour of his rivals, dissolved. Concerted efforts targeting Mubarak have now diffused; Egypt is in the process of forging a new system of constraints. 
The study of collective restraints provides a novel theoretical entry into contentious politics. It contributes to our questions on how, when, and why political protests develop and transform, employ or abstain from using violence, accentuate or inhibit the usage of certain slogans. The framework developed here may throw light on other cases such as Bahrain, where the uprising remains peaceful, or Syria where the protest turned violent. The starting point would be to demarcate the system of cultural and material contexts that enable or constrain contentious actors.

\section{Notes}

${ }^{1}$ Commenting on the Egyptian revolution, President Barack Obama noted: 'Egyptians have inspired us, and they've done so by putting the lie to the idea that justice is best gained through violence. For in Egypt, it was the moral force of nonviolence - not terrorism, not mindless killing -but nonviolence, moral force that bent the arc of history toward justice once more. See 'Remarks by the President' available from http://www.whitehouse.gov/the-press-office/2011/02/11/remarks-president-egypt

2 El-Ghobashy, 2012; Beissinger, 2011; Reicher, 2011; Ismail, 2011; El-Mahdy, 2011; El-Mahdy, 2009; Reiss, 2007; Alexander et.al., 2006; Tilly, 2008; Schwedler, 2006; Tilly, 2006; Eyerman, 2006; Steinberg, 1999; Ellingson, 1995.

${ }^{3}$ One exception is Tyler and Degoey (1995) who examine 'collective restraint in social dilemmas'; but their study focuses on how people in the case of the 1991 California water shortage chose to support existing authorities not on collective political protest.

${ }^{4}$ I carried 14 semi-structured interviews in Cairo in the period 25 April - 07 May, 2012. The sample included individuals from different ideological inclinations (Islamists, Socialists, Liberals, and independents) who participated in the Midan demonstrations. All interviews were conducted in Arabic. In addition to the interviews I draw information from first hand accounts available in books, documentaries, speeches and YouTube clips. All quotations from Arabic sources in the article are my own translation.

${ }^{5} \mathrm{~A}$ regime is 'an alliance of dominant ideological, economic, and military power actors coordinated by the rulers of the state' (Mann, 1993, p.18-19)

${ }^{6}$ One song of the 'Ultras Ahlawi' football team talks about a regime that imposed a choice on its people 'between its rule and chaos in the country'. See 'Hikayatna' [Our story] available at http://www.youtube.com/watch?v=F2hYgkXjdJI

${ }^{7}$ In that incident, which continued for more than 12 hours, football supporters of both Ahli and Zamalek teams and organised members of the Muslim Brothers helped defend the Midan against the camel invasion (Personal interviews 2012).

8 Building on Elias, Fletcher (1997/2005, 83-4) argues that external constraints collapse with 'shifts in the balance of social constraint and self-restraint, changes in the social standards of feeling and behaviour, and changes in the scope of mutual identification', which result because of 'a decrease in the (state) control of the monopoly of violence, a fragmentation of social ties and a shortening of chains of commercial, emotional and cognitive interference'.

9 The case in point is Lara Logan, a journalist, who was sexually assaulted and raped as she was covering the event in the Midan : http://www.youtube.com/watch?v=1E1Ld93qyXc . Accessed on 13 February 2013. On the second anniversary of the revolution, 19 cases of sexual harassment against women were recorded in the Midan, see http://observers.france24.com/ar/content/20130213. Accessed on 19

February 2013. 


\section{References}

Alexander, J. (2011) Performative Revolutions in Egypt: An essay in cultural power. New York: Bloomsbury Academic.

(2006) 'Cultural pragmatics: social performance between ritual and strategy' in J. C. Alexander, B. Giesen, and J. L. Mast (eds.) Social Performance: Symbolic Action, Cultural Pragmatics, and Ritual. Cambridge: Cambridge University Press, pp. 29-90.

Al-Jamal, K. (2011) shiarat thawrat 25 yanayer [Slogans of the 25 January revolution]. Cairo: Maktabat Jaridad Al-Ward

Al-Sheikh. M. (2011) 'al-Tatheer al-Tonisi fi al-thawra al-misriya: min sidi bouzeid ila al-tahrir [The Tunisian influence on the Egyptian revolution: from Sid Bouzeid to Tahrir] in A. Hussein (ed.) (2011) Youmiyat althawra al-Masriya, yanayer 2011 [Days of the Egyptian Revolution: January 2011]. Beirut: Arab Scientific Publishers, Inc.

Awad, M. (2013) 'Mutazahirou port said yarfaoun alam gheir alam misr [Port Said protesters carry their own flag]', available from http://www1.youm7.com/News.asp?NewsID=930090\&SecID=12 . Accessed on 8 February 2013.

Badawi, M. (2011) '25 was 28 yanayer..al-tareek ila al-tahrir [25 and 28 January..the road to Tahrir] in A. Hussein (ed.) (2011) Youmiyat al-thawra al-Masriya, yanayer 2011 [Days of the Egyptian Revolution: January 2011]. Beirut: Arab Scientific Publishers, Inc.

BBC (2011) 'Egypt Unrest: Full text of Mubarak's Speech', http://www.bbc.co.uk/news/mobile/worldmiddle-east-12427091, accessed on 15 September 2013.

Carr, Sarah, 'April 6: Geneology of a Youth Movement http://www.jadaliyya.com/pages/index/4950/april-6 genealogy-of-a-youth-movement, accessed on 23 September 2013.

Chehabi, H.E. and Linz, J. (eds.) (1998) Sultanistic Regimes. Baltimore and London: The John Hopkins University Press.

Clark, K. (2011) 'Saying "Enough": Authoritarianism and Egypt's Kefaya Movement', Mobilization: An International Journal, 16 (4), 397-416.

Darwich, May (2013) Personal interview.

El-Ghobashy, M. (2012) 'The Praxis of the Egyptian Revolution', in J. Sowers and C. Toensing (eds.), The Journey to Tahrir: Revolution, Protest, and Social Change in Egypt. London and New York :Verso, pp. 21-40.

El-Mahdi, R. (2009) 'The democracy movement: cycles of protest' in R. El-Mahdi and P. Marfleet (eds.) Egypt: Moment of Change. Cairo: The American University in Cairo Press, pp. 87-102

El-Mahdi, M. (2011) Abkariat al-thawra al-Masria: tahlil nafsi wa igtimai li ahwal al-masriyeen kabl wa baad 25 yanayer [The Ingenuity of the Egyptian revolution: a socio-psychological analysis of the state of Egyptian before and and after 25 January]. Cairo: Dar Al-Shourouk.

El-Mohamady, M. (2012) Sana oula thawra [First Anniversary Revolution]. Cairo: Dar Al-Nahda Misr.

Elias, N. (2000) The civilizing process: sociogenetic and psychogenetic investigations. Oxford: Blackwell. 
Ellingson, S. (1995), 'Understanding the Dialectic of Discourse of Collective Action: Public Debate and Rioting in Antebellum Cincinnati', American Journal of Sociology, 101 (1), 100-44.

Eyerman R. 'Performing opposition or, how social movements move' in J. C. Alexander, B. Giesen, and J. L. Mast (eds.) Social Performance: Symbolic Action, Cultural Pragmatics, and Ritual, Cambridge: Cambridge University Press, pp.193-217

Fletcher J. (1997/2005), Violence \& Civilization: An introduction to the work of Norbert Elias, Cambridge: Polity Press

Hussein, A. (2011) 'Muqadima: qiam al-thawra al-Masriya [Introduction: the values of the Egyptian revolution]', in A. Hussein (ed.) (2011) Youmiyat al-thawra al-Masriya, yanayer 2011 [Days of the Egyptian Revolution: January 2011]. Beirut: Arab Scientific Publishers, Inc.

Hussein, A. (2012) Personal interview. Cairo.

Ismail, S. (2011) 'The Syrian Uprising: Imangining and Performing the Nation', Studies in Ethnicity and Nationalism, 11 (3), 538-549.

'Joumhouriyat al-Tahrir' [The Midan Republic], Aljazeera Documentary available at http://www.youtube.com/watch?v=dUNcQ6VViaY, accessed on 16 February 2013

Khashan, H. (1995) 'Nasir's Commitment to Arab Unity in Retrospect', Palma Journal, 3, (2), 41-58.

Kitschelt, H.P. (1986) 'Political Opportunity Structures and Protest: Anti-Nuclear Movements in Four Democracies', British Journal of Political Sicence, 16 (1), 57-85.

Klein, O. and Licata, L. (2003) 'When group representations serve social change: The speeches of Patrice Lumumba during the Congolese decolonization', British Journal of Social Psychology, 42, 571-593

Le Bon, G. (1896, 1947) The Crowd: A study of the Popular Mind. London: Ernest Bent Limited.

Maghdi, A. (2011) “"koulouna khaled saeed”..shaheed yarhal wa shaab youbaath ["we are all Khaled Said”..a martyr leaves and a people revive'] in A. Hussein (ed.) (2011) Youmiyat al-thawra al-Masriya, yanayer 2011 [Days of the Egyptian Revolution: January 2011]. Beirut: Arab Scientific Publishers, Inc.

Mann, M. (1993) The Sources of Social Power. Cambridge: Cambridge University Press.

Matta, W. (2013) 'Mushahadat ala khat alfasel bayna althawra..wa alfawda [Scenes on the fault line of revolution and anarchy', As-Safir 30 January.

Mecham, Q. (2004) 'From the Ashes of Virtue, a Promise Light: The Transformation of Political in Turkey', Third World Quarterly, 25 (2), 339-58.

Naguib, S. (2009) 'Islamism(s) old and new' in R. El-Mahdi and P. Marfleet (eds.) Egypt: Moment of Change. Cairo: The American University in Cairo Press, pp.103-9.

Reicher, S. (2011), 'Mass action and mundane reality: an argument for putting crowd analysis at the centre of the social sciences', Contemporary Social Science: Journal of the Academy of Social Sciences', 6 (3), 433-449

Reicher, S.D., Spears R., and Postmes, T (1995), 'A Social Identity Model of Deindividuation Phenomena', European Review of Social Psychology', 6 (1), 161-198

Reicher, S. and Stott, C. (2007) 'Becoming the Subjects of History: An outline of the Psychology of Crowds' in M. Reiss (ed.), The Street as Stage: Protest Marches and Public Rallies since the Nineteenth Century. Oxford: Oxford University Press, pp. 25-41 
Reiss, M. (2007) (ed.), The Street as Stage: Protest Marches and Public Rallies since the Nineteenth Century. Oxford: Oxford University Press, pp. 25-41

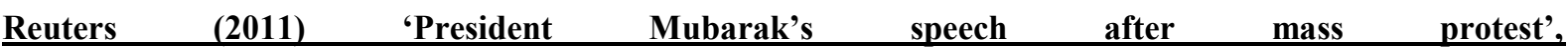
http://www.reuters.com/article/2011/02/01/egypt-mubarak-speech-idAFLDE7102JP20110201, accessed on 16 September 2013.

Saad, A. (2012) Mashahed min qalb al-thawra [Scenes from the heart of the revolution]. Cairo: Al-Ahram Center for Translation, Publishing and Distribution.

Saouli, A. (2011) 'Hizbullah in the Civilising Process: Anarchy, self-restraint and violence' , Third World Quarterly, 32 (5), 925-42.

(2012) The Arab State: Dilemmas of late formation. London and New York: Routledge

Schwedler, J. (2006) 'Cop Rock: Protest, identity, and Dancing Riot Police in Jordan', Social Movement Studies: Journal of Social, Cultural and Political Protest, 4 (2), 155-175.

Seif, O. (2012) Personal interview. Cairo.

'Silmiya' [Peaceful], ONTV documentary available at http://www.youtube.com/watch?v=P1MRwTPBqWA, accessed on 13 January 2012.

Shokr, A. (2012) 'The Eighteen Days of Tahri', in J. Sowers and C. Toensing (eds.), The Journey to Tahrir: Revolution, Protest, and Social Change in Egypt. London and New York :Verso, pp.41-46.

Tabei, H. (2012) Personal Interview. Cairo.

'The Truth about the Egyptian youth revolution' (2011), video uploaded on YouTube, available at athttp://www.youtube.com/watch?v=rSSA4ol1a8s\&playnext=1\&list=PLDE0057BB6232807F\&feature=results_ video. Accessed on 11 February 2013.

Tilly, C. (2005) Identities, boundaries, and social ties Boulder, Colorado.: Paradigm (2006) Regimes and Repertoires. Chicago: University of Chicago Press. (2008) Contentious Performances. Cambridge and New York: Cambridge University Press.

Tyler, R. and Degoey, P. (1995) 'Collective restraint in social dilemmas: Procedural justice and social identification effects on support for authorities', Journal of Personality and Social Psychology, 69 (3), $482-497$.

Wedeen, L. (1998) 'Acting “As if”: Symbolic Politics and Social Control in Syria', Comparative Studies in Society and History, 40 (3), 503-523.

Williams R. H (2004), 'The Cultural Contexts of Collective Action: Constraints, Opportunities, and the Symbolic Life of Social Movements', in David A. Snow, Sarah A. Soule, and Haspeter Kriesi (eds), The Blackwell Companion to Social Movements, Victoria, Austrialia: Blackwell Publishing. 